\title{
The Grounding of Conceptual Metaphor in Bodily Experience
}

\author{
Ajang Budiman \\ University of Muhammadiyah Malang \\ ajangbudiman99@gmail.com
}

\begin{abstract}
The capacity using and understanding language is a special gift from God to human being, and metaphor is one of those features contributing to that specialty. Metaphor, viewed from a cognitive viewpoint, is a kind of thinking or understanding something in terms of something else. This poses the problem of the possibility of grounding metaphor in experience, that is the grounding of understanding one thing in terms of another. This is the problem of grounding. This article investigates that problem by analysing daily metaphors as they are used in newspaper news story by employing cognitive framework. Based on the analysis of the various metaphors used in the news text, it is found that those metaphors are based on correlations with the bodily experience (as it appears in spatial metaphors) and a certain anthropomorphistic tendency (as it appears in personification). Thus, the investigation into the foundation of metaphors shows that ontologically there are dynamics between human situatedness in the world and human activity as agents whose position as the center of experience.
\end{abstract}

Keywords: conceptual metaphor, grounding, bodily experience, news report

\section{INTRODUCTION}

One of many human miracles is his capacity to speak and understand language. This is said so because by producing a stretch of articulated sounds or verbal marks on papers; one can talk about something hidden in his mind or lay open in the external world, and the listener/reader can understand it meant by a speaker/writer. Although to some extent some other creatures, especially animal, can be assumed to have language, in which "language" is very different from human's. In its most important aspect, apart of the language of other creatures, human language forms part of his identity as human being; language is part of his endeavour to develop culture which belongs to human world different from natural world. Underlying these fundamental aspects of language, Enst Cassirer calls human beings as animal symbolic um [1]. It is due to this capacity of symbols that human beings have not only natural reality, but also what is called socially constructed reality [2].

In this context, metaphor is just one striking feature of language contributing to the miraculous nature of language, because it allows us to talk about one thing but means another. Metaphor is about the way we use words to express certain meanings. The general way, or at least it is thought so, to use words is that we use words to express meaning directly or, as Halliday put it, "congruently". However, in many cases we also talk about things indirectly. In poems the poets often use metaphor to foreground certain meaning. When Chairil Anwar (the proponent of modern Indonesian poetry in 1940's) called himself a "wild animal" (binatang jalang), it was certainly not intended to mean that he was an animal, but did highlight certain aspects of human freedom whose willing not to be oppressed. When President Soekarno (the first president of Indonesia) talked about independence as a "golden bridge", he was not talking about the concrete bridge, but the important means to achieve national objectives of justice and prosperity. These examples might lead us to the conclusion that metaphor is a special use of poets and orators.

However, Lakoff and Johnson [3] tried to convince us that metaphor is not primarily a special use of language, but a general and widespread characteristics of language use in all fields of life. Metaphor is not confined to literary works or persuasive speeches, but pervasive in our daily life as mundane as commenting on football matches to as solemn activities as our pray to God. The reason is that because metaphorical linguistic expressions are just manifestation/realization of conceptual metaphor which underlies it. Conceptual metaphor is formulated as $\mathrm{A}$ is $\mathrm{B}$, for example argument is war; this conceptual metaphor is manifested/realized in linguistic metaphors such as Your argument is indefensible. A is the target concept (topic, tenor) and B is the source concept (vehicle) which is used to talk about $\mathrm{A}$, with $\mathrm{B}$ being the justification for A.

This article is not intended to discuss all aspects of the important of conceptual metaphors; but focused its attention on the question of grounding metaphor in experience. How is it justified to talk about a target concept (e.g. argument) in terms of another (e.g. war)? Why cannot we use any concept (e.g. food) to talk about war? What is it that constrains it? This is the problem of the basis of metaphor [4] or the grounding of metaphor [5]. Traditionally this problem is answered by saying that metaphor is grounded on similarity between entities denoted by the metaphorical words as when we talk about "the roses on her cheek". However, on further studies, this investigation raises indefensible answer because there is a similarity between numbers and verticality in the metaphor for example 'more' is 'up' which are dissimilar concepts [6]. In modern theory of 
metaphor it is said that metaphor is not necessarily based on similarity, but metaphor is naturally based or grounded on bodily experience (embodiment) [7]. Hence, this article is focused on the grounding of metaphor on bodily experience.

\section{METHOD}

Answering the questions of metaphor grounding, this article relies on Cognitive Linguistics as its theoretical orientation, especially on conceptual metaphor theory, which sees language as a cognitive/conceptual phenomenon and means of communication. It sees language as a conceptual means of communication which is rooted in bodily experiences [8], [9], [10]. The method of investigation used is basically descriptive and qualitative by describing the use of metaphor in natural language of daily life. The source of data is news stories of the newspaper Kompas, during April 2013, which has also been used by [11] for different purposes. The language of newspaper is a proper object of research because it represents a language event in a society [12]. The data showed highlighting lexical units contain the guides of metaphors given by Schmitt [13] and Pragglejaz group [14]. Both guides have similarities in that both rely on the differences between literal and contextual meanings for the identification of metaphorical words/expressions. The next stage of analysis is examining the relation between the target and the source concepts in conceptual metaphors to identify the grounding of metaphors on bodily experience.

\section{RESULT}

Based on the data analysis, it is found that there are a variety of relationships between the target and the source concepts in the conceptual metaphor. In general, the relationship between the two is between abstract concepts as target concepts and concrete concepts as source concepts. Thus, there is a conceptualization of abstract concepts as concrete concepts. For example, time (opportunity) is conceptualized as space (e.g. in "menutup ruang-ruang yang memungkinkan bagi setiap aparatur negara melakukan tindak pidana korupsi" ["closing spaces that make it possible for every state apparatus to commit corruption"], socio-political institutions are conceptualized as individuals (eg, "Ini masalah ego sektoral. Bahkan banyak kementerian yang tidak rela kewenangannya tereduksi" ["This is a sectoral ego problem. Even many ministries which are not willing to reduce his authority"]), as well as abstract intellectual processes such as knowing or understanding as concrete actions to see (eg in "Apresiasi juga disampaikan oleh seorang pengamat yang melihat keterbukaan itu sebagai budaya baru" ["Appreciation is also conveyed by an observer who sees openness as a new culture "]. These examples seem to confirm the basic tenet of Cognitive Linguistics that the metaphor (and the use of language in general) is based on bodily experience.
In further observation it is found that the conceptual metaphors that underlie linguistic metaphors are based on correlations with experience and on anthropomorphism. The first manifestation of grounding on correlation in bodily experience is a top-down (verticality) metaphor which is based on the experience that the accumulation of increasingly greater quantity of goods will appear as an increasingly high pile. Thus, there is a correlation between quantity and verticality. The correlation is formulated as the conceptual metaphor, quantity is verticality. In this study, top-down metaphors manifest in various linguistic expressions such as "merosot" (degenerate), "turun" (down), "menurun" (lower), "naik" (up), "menaikkan" (raise), and "meningkat" (rise) that are used in connection with reductions in fuel subsidies and its consequence on price increases and other expenses. Thus, fuel subsidies are "lowered", causing prices to "rise", other costs also "rise", including unemployment also "rises", but business transactions "decline".

The second manifestation of the metaphorical grounding in the form of the correlation in bodily experience is the inside-outside metaphor (the metaphor of space/container). Being outside and being inside are a direct human experience, as when he is inside his house or outside it, as well as when putting something into the inside of a container. In this research, there are examples of the application of the inside-outside image schema as to the institution of KPK (The Commision of Corruption Eradication) when it is told more or less "Do not let the KPK fuss inside, but outside, it doesn't function". In this example KPK is metaphorically likened to a container that has an inside and an outside. In this example the inside is the internal affairs of the KPK regarding the relationship between KPK leaders, while the outside is the relationship of KPK with other institutions as well as other parties. Examples of metaphors based on correlations in bodily experience show that man is 'being' in this world as the 'being' has been defined in phenomenology.

The second grounding is the anthropomorphism that sees everything from the standpoint of the man himself. The first and foremost manifestation of anthropomorphism is personification, which conceptualizes non-human, especially inanimate objects as living human beings. Coconut trees that are swayed by the movement of the wind is called "melambai" (waving), as if the palm had hands and will do as human beings do which do the act of "waving". In this study there are many examples of personification of natural phenomena as human beings, as well as social institutions as individuals, also man-made activities and objects conceptualized as people.

The second manifestation of anthropomorphism is the front-back metaphor. For objects that have a 'front and back' section, the 'fronts' and the 'backs' may change the other way around. However, for objects that do not have front-back parts, humans mention the front and back based on their own perspective. All objects that exist between the flag and himself are called in front of the flag, while all objects located after the flag are called 
that they are behind the flag. In this case it is clear that in the front and in the back is not an attribute of an object but is attributed to things according to the viewing person's perspectives. The example found in this study is a flag; there is an expression of people standing behind the flag, whereas the flag has no back. Analogically, this makes sense based on that perspectivism. Examples of anthropomorphism show the role of humans as active agents in the world.

Thus, ontologically speaking there is a dynamics between human situatedness in the world and human activity as an agent who uses himself as the center of experience.

\section{CONCLUSION}

The analysis of linguistic metaphors used in newspaper news story shows that the use of metaphors is based on bodily experiences. Specifically, it is found that the use of metaphor is based on correlation in bodily experiences and on anthropomorphism, which puts human as 'beings' bound to the world and as an active agent overcoming / performing the world. This study is limited to general depictions without looking at the productivity and distribution of those metaphors in various fields and media. Therefore, more detailed and extensive research are needed to cover the variety of fields and media.

\section{REFERENCES}

[1] Ernst Cassirer, An Essay on Man, Yale University Press, 1944 (Indonesian translation: Manusia dan Kebudayaan: Sebuah Esai tentang Manusia, Gramedia, 1987).

[2] Berger dan Luckman, Social Construction of Reality: A Treatise in the Sociology of Knowledge, Penguin Books, Harmmondsworth, Middlessex, 1971. Pages 1, 149.

[3] George Lakoff and Mark Johnson, Metaphors We Live By, The University of Chicago Press, London, 2003.

[4] Zoltán Kö̀vecses, Metaphor: A Practical Introduction, second edition, Oxford University Press, Oxford, 2010, page 77.
[5] George Lakoff and Mark Johnson, Metaphors We Live By, The University of Chicago Press, London, 2003.

[6] Zoltán Kövecses, Metaphor: A Practical Introduction, second edition, Oxford University Press, Oxford, 2010, page 78.

[7] Raymond W. Gibbs Jr., Paula Lenz Costa Lima, Edson Francozo, "Metaphor is grounded in embodied edxperience", in Journal of Pragmatics, 36 (2014), pages 1189-1210.

[8] Rene Dirven, "Cognitive Linguistics", in Kirsten Malmkjær, ed. The Routledge Linguistics Encyclopedia, third edition, Routledge, Abingdon and New York, 2010; pages 61-68.

[9] Dirk Geeraerts and Hubert Cuyckens, "Introducing Cognitive Linguistics", in Dirk Geeraerts and Hubert Cuyckens, eds., Oxford Hanbook of Cognitive Linguistics, Oxford University Press, Oxford, 2007; pages 3-21.

[10] Janda, "Cognitive Lingnstics in the Year 2010", in Internatonal Journal of Cognitive Linguistics, Volume 1 Issue 1, 2010, pages 1-30.

[11] Ajang Budiman, Djoko Saryono, Anang Santoso, and Maryaeni, "Discourse Aspect of Metaphor in Indonesian Newspaper", in International Journal of Science and Research (IJSR), Volume 6 Issue 8, August 2017, pages 230-235.

[12] Douglas Biber and Susan Conrad, Register, Genre, and Style, Cambridge University Press, Cambridge, 2009.

[13] Rudolf Schmitt, Systematic Metaphor Analysis as a Method of Qualitatiave Research, in The Qualiatiave Report, Vol. 10, No. 2, June 2005; pages 358 -394.

[14] Zoltán Kövecses, Metaphor: A Practical Introduction, second edition, Oxford University Press, Oxford, 2010, page 4. 